\title{
The Demographic and Clinical Features of 479 COVID-19 Patients: A Single-center Experience
}

\author{
Dört Yüz Yetmiş Dokuz COVID-19 Hastasının Demografik ve Klinik Özellikleri: Tek Merkez \\ Deneyimi
}

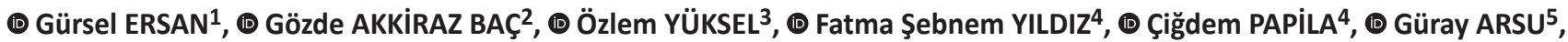

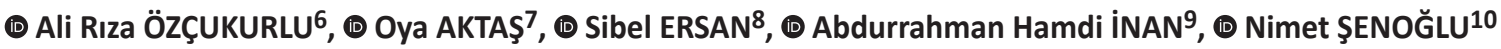 \\ 1 University of Health Sciences Turkey, Izmir Tepecik Training and Research Hospital, Clinic of Infectious Diseases and Clinical Microbiology, Izmir, Turkey \\ 2 Menemen State Hospital, Clinic of Infectious Diseases and Clinical Microbiology, Izmir, Turkey \\ ${ }^{3}$ Aliağa State Hospital, Clinic of Infectious Diseases and Clinical Microbiology, Izmir, Turkey \\ ${ }^{4}$ Bornova Türkan Özilhan State Hospital, Clinic of Infectious Diseases and Clinical Microbiology, Izmir, Turkey \\ ${ }^{5}$ Aliağa Criminal Institutions Campus State Hospital, Clinic of Infectious Diseases and Clinical Microbiology, Izmir, Turkey \\ 6Urla State Hospital, Clinic of Infectious Diseases and Clinical Microbiology, Izmir, Turkey \\ ${ }^{7}$ Buca Obstetrics-Gynecology and Children Hospital, Clinic of Infectious Diseases and Clinical Microbiology, izmir, Turkey \\ 8 University of Health Sciences Turkey, Izmir Tepecik Training and Research Hospital, Clinic of Internal Medicine, Division of Nephrology, Izmir, Turkey \\ ${ }^{9}$ Bornova Türkan Özilhan State Hospital, Clinic of Obstetrics and Gynecology, Izmir, Turkey \\ 1 OUniversity of Health Sciences Turkey, Izmir Tepecik Training and Research Hospital, Clinic of Intensive Care, Izmir, Turkey
}

\section{Abstract}

Introduction: A pandemic emerged in 2020 in Wuhan, China because of severe acute respiratory syndrome-coronavirus-2 (SARS-CoV-2) virus infection. It rapidly disseminated all over the world in a short time. This study described the demographic and clinical features of 479 coronavirus disease-2019 patients admitted to a designated pandemic hospital in İzmir, Turkey, and it aimed to incorporate our experiences into current literature.

Materials and Methods: Patients confirmed with symptomatic SARS-CoV-2 infection by real-time polymerase chain reaction or by typical chest computed tomography findings and rapid antibody test positivity were enrolled in the study. Demographic and clinical data of the patients were extracted from electronic medical recordings. The patients were categorized into three groups based on the severity of clinical and laboratory findings: group 1, uncomplicated disease; group 2, mild/moderate disease; and group 3, severe disease. Demographic and clinical findings were compared between groups.

Results: The mean age of the patients was $50.7 \pm 19.3$ years; $50.5 \%$ of the patients were male. No significant difference was observed between gender distributions in groups. The most common symptoms on admission were cough (219,45.7\%), fever (187, 39\%), fatigue (176, 36.7\%), and dyspnea $(63,13.2 \%)$. The most frequently observed comorbidities were hypertension $(129,26.9 \%)$, diabetes $(71,14.8 \%)$, and chronic heart diseases $(35,7.3 \%)$. The patients in group 3 had shown significantly higer number of underlying diseases. On chest computed tomography, ground-glass opacity was the most common radiologic finding. C-reactive protein, D-dimer, ferritin, and procalcitonin were found to be in significantly increased levels in patients with severe disease.

Conclusion: Our observations during the first three months of pandemic suggested that the patients can present with a varying degree of severity. Some prognostic markers can predict the progression of the disease. We emphasize that accumulating experiences in the management of the disease accompanied by up-to-date tracking of guidelines would enable us to face up against upcoming surges more effectively.

Keywords: COVID-19, laboratory findings, clinical features, treatment

Cite this article as: Ersan G, Akkiraz Baç G, Yüksel Ö, Yıldız FŞ, Papila Ç, Arsu G, Özçukurlu AR, Aktaş O, Ersan S, İnan AH, Şenoğlu N. The Demographic and Clinical Features of 479 COVID-19 Patients: A Single-center Experience. Mediterr J Infect Microb Antimicrob. 2020;9:9. 
Giriş: Çin'in Wuhan şehrinde 2020 yılında şiddetli akut solunum sendromu-koronavirüs-2 virüs enfeksiyonuna bağlı bir pandemi ortaya çıkmıştır. Pandemi kısa sürede dünya çapında yayılmış ve giderek bilgi birikimi artmıştır. Bu çalışmada belirlenmiş bir pandemi hastanesinde izlenen 479 koronavirüs hastalığı-2019 hastasının demografik ve klinik özellikleri tanımlanmıştır ve deneyimlerimizin güncel literatüre kazandırılması amaçlanmıştır.

Gereç ve Yöntem: Gerçek zamanlı polimeraz zincir reaksiyonu veya tipik toraks bilgisayarlı tomografi bulguları olup hızlı antikor pozitifliği ile tanı alan semptomatik hastalar çalışmaya alınmıştır. Demografik ve klinik veriler elektronik tıbbi kayıtlardan elde edilmiştir. Klinik ve laboratuvar bulgularının derecesine göre hastalar üç grupta sınıflandırılmıştır; grup 1: komplikasyonsuz hastalık, grup 2: hafif/orta hastalık, grup 3: ciddi hastalık. Gruplara ait demografik ve klinik veriler karşılaştırılmıştır.

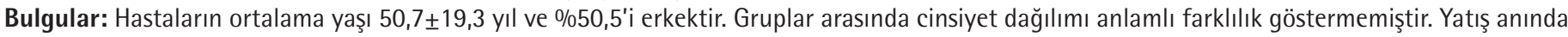
saptanan en sık semptomlar; öksürük $(219, \% 45,7)$, ateş $(187, \% 39)$, halsizlik $(176, \% 36,7)$ ve dispne $(63, \% 13,2)$ olarak gözlendi. En sık eşlik eden hastalıklar; hipertansiyon $(129, \% 26,9)$, diyabet $(71, \% 14,8)$ ve kronik kalp hastalıklarıdır $(35, \% 7,3)$. Grup 3 hastalarında komorbidite sayısı anlamlı olarak fazla bulundu. Toraks tomografisinde buzlu cam görünümü en sık bulguydu. C-reaktif protein, D-dimer, ferritin ve prokalsitonin düzeyleri ciddi hastalık grubunda anlamlı yüksek saptandı.

Sonuç: Pandeminin ilk üç ayına ait gözlemlerimize göre başvuruda hastalık şiddeti değişken olabilmekte ve bazı faktörler prognozu belirleyebilmektedir. Çalışmamızda hastalığın yönetiminde edinilen tecrübeler ve güncel rehberlerin takibi ile yeni atakları daha etkin karşılaşayabileceğimizi vurguladık. Anahtar Kelimeler: COVID-19, laboratuvar bulgular, klinik bulgular, tedavi

\section{Introduction}

A cluster of pneumonia cases with unknown etiology originated in Wuhan, China, in December 2019. The disease rapidly spread and resulted in a global pandemic and described as coronavirus disease-2019 (COVID-19) standing for coronavirus disease in 2019, caused by severe acute respiratory syndromecoronavirus-2 (SARS-CoV-2) ${ }^{[1,2]}$. SARS-CoV-2 is a new, enveloped beta coronavirus that phylogenetically resembles previously described SARS-CoV and Middle East respiratory syndrome-CoV $(\mathrm{MERS}-\mathrm{CoV})^{[3]}$.

The disease has a spectrum of asymptomatic infection of mild/ moderate pneumonia and/or severe respiratory syndrome with fatal outcomes ${ }^{[4]}$. The prevalence of asymptomatic SARS-CoV-2 infection has not been known yet. Complaints generally begin within one week with predominating symptoms of fever, cough, nasal congestion, and fatigue in symptomatic cases. Pneumonia is encountered in approximately $75 \%$ of symptomatic patients and usually develops in the second or third weeks of the disease. The radiologic findings on chest computed tomography (CT) include ground-glass opacities, patchy consolidation sites, consolidations with ground-glass opacities, and infiltrations. The laboratory evaluation frequently displays lymphopenia and an increase in inflammatory markers ${ }^{[5]}$. The primary diagnostic tool is to detect viral RNA by a nucleic acid amplification test, reverse transcription-polymerase chain reaction (RT-PCR) [6]. Currently, there has been no evidence-based management for COVID-19. World Health Organization (WHO) recommends empirical antimicrobial therapy and respiratory support based on the severity of the disease. Several Asian countries established therapeutic protocols including hydroxychloroquine, chloroquine phosphate, remdesivir, and lopinavir/ritonavir as a case-based approach ${ }^{[7]}$. In our country, favipiravir has been used, yet remdesivir is not available.

This study aims to incorporate the experiences in the management of COVID-19 patients to current literature and effectively face up to resurgence of the disease.

\section{Materials and Methods}

\section{Patient Recruitment and Data Collection}

A city state hospital, namely Bornova Türkan Özilhan State Hospital, is converted to a pandemic hospital by İzmir Health Office since the emergence of the first COVID-19 patient on March 15, 2020, in İmir. Medical staff from other hospitals such as infectious disease specialists, intensive care specialists, and health caregivers were recruited to this hospital. Only symptomatic confirmed or suspicious COVID-19 patients were admitted to the hospital.

During the first wave of the pandemic, between March 15 and May 31, 2020, 479 patients aged $\geq 18$ years, out of 1,364, with confirmed COVID-19 by RT-PCR or by typical chest CT findings and rapid antibody test were enrolled in the study. According to the national guideline ${ }^{[8]}$, patients were categorized into three disease groups based on severity of the symptoms and laboratory and radiologic findings:

Uncomplicated disease (group 1): Patients with symptoms of fever, myalgia/arthralgia, cough, and nasal congestion but no dyspnea/tachypnea, oxygen saturation in room air $\left(\mathrm{SpO}_{2}\right)$ $>93 \%$, no poor prognostic markers (lymphocyte count $<800$ / $\mu \mathrm{l}$ or C-reactive protein (CRP) $>40 \mathrm{mg} / \mathrm{l}$ or ferritin $>500 \mathrm{ng} / \mathrm{ml}$ or D-dimer $>1000 \mathrm{ng} / \mathrm{ml}$ ) on admission, and normal radiologic findings. 
Mild/moderate disease (group 2): Patients with symptoms of fever, myalgia/arthralgia, cough, nasal congestion and sore throat, respiratory rate $<30 / \mathrm{min}_{1} \mathrm{SpO}_{2}>90 \%$, no poor prognostic markers (lymphocyte count $<800 / \mu \mathrm{l}$ or $\mathrm{CRP}>40 \mathrm{mg} / \mathrm{l}$ or ferritin $>500 \mathrm{ng} / \mathrm{ml}$ or D-dimer $>1,000 \mathrm{ng} / \mathrm{ml}$ ) on admission, and signs of mild pneumonia on chest CT.

Severe disease (group 3): Patients with symptoms of fever, myalgia/arthralgia, cough, nasal congestion and sore throat, with tachypnea (respiratory rate $\geq 30 / \mathrm{min}$ ) and $\mathrm{SpO}_{2}<90 \%$, and with poor prognostic markers (lymphocyte count $<800 / \mu l$ or CRP $>40 \mathrm{mg} / \mathrm{l}$ or ferritin $>500 \mathrm{ng} / \mathrm{ml}$ or D-dimer $>1,000 \mathrm{ng} / \mathrm{ml}$ ) on admission, and bilateral pneumonia signs on chest CT.

We extracted the data of epidemiological, clinical, laboratory, and radiologic findings of patients on admission from electronic medical records.

\section{Laboratory Investigations}

The definitive diagnosis was made by the detection of SARSCoV-2 virus by RT-PCR from oropharyngeal and nasopharyngeal swabs. All patients had laboratory investigations on admission and at least two times a week during follow-ups. Chest CT imaging was obtained from all patients except for pregnant patients who did not give consent.

\section{In-hospital Follow-up}

Patients were admitted to single rooms when available otherwise in double-bed rooms with $1.5 \mathrm{~m}$ distance between beds. The admission dates for patients in double-bed rooms were not beyond three days; worn masks and attending people were not allowed unless deemed necessary. The rooms were frequently ventilated.

If oral intake was inadequate, intravenous fluid resuscitation was done. Hypoxic patients were given nasal oxygen 3-5 I/min with a target $\mathrm{O}_{2}$ saturation of $93 \%$.

Hydroxychloroquine with or without azithromycin was given to all patients of groups 1 and 2. Hydroxychloroquine with azithromycin was given to all patients of group 3, and favipiravir was began initially depending on case-by-case evaluation or as an add-on in case of clinical deterioration. The attending physicians determined the antibiotic choice. With respect to the the local epidemiological data and the inability to rule out seasonal influenza, oseltamivir was included in the treatment regime to patients who are not given favipiravir. The patients with critical progression received convalescent immune plasma in between seventh and fourteenth days of the disease. Anticytokine therapy was not given to any patient.

Critical care unit admission criteria included a respiratory rate $>30 /$ min despite oxygen therapy, dyspnea progression, and $\mathrm{SpO}_{2}$ $<90 \%$ in room air.
The patients with normal $\mathrm{SpO}_{2}$ and without respiratory symptoms and fever in the last three days were discharged from the hospital.

\section{Statistical Analysis}

Percentages and mean \pm standard deviation were calculated to describe the distributions of categorical and continuous variables, respectively. $P$ values for differences between variables in groups were tested using a chi-squared test for categorical data and a t-test for parametrical and Mann-Whitney $\mathrm{U}$ test for nonparametric continuous data. All analyzes were performed using the SPSS statistical package (version 25.0; SPSS Inc, Chicago, IL). A two-sided $p$ value of 0.05 was considered statistically significant.

\section{Results}

\section{Demographic and Clinical Characteristics}

Of the 1,364 patients who applied to the hospital, 479 COVID-19 patients (35.1\%) were admitted. Clinical, demographic, and laboratory features were shown in Table 1.

Groups 1, 2, and 3 comprised 130 [27.1\%, 67 men (51.5\%)], 300 [62.6\%, 154 men (51.3\%)], and 49 patients [10.2\%, 20 men $(40.8 \%)]$, respectively; $242(50.5 \%)$ of patients were male; and the mean age of patients was $50.7 \pm 19.3$ years. The patients in group 3 were significantly older ( $67.8 \pm 17.5$ years) than those of groups 1 and 2 ( $p=0.001$ for both).

Common symptoms on admission were cough $(219,45.7 \%)$, fever $(187,39 \%)$, fatigue $(176,36.7 \%)$, and dyspnea $(63,13.2 \%)$. The interval between the onset of symptoms and hospital admission in groups 1,2 , and 3 patients was $1.7 \pm 2.2,4.2 \pm 3.9$, and $3.4 \pm 3.2$ days, respectively. The interval was significantly higher in groups 2 and 3 patients as compared to group 1 ( $p=0.001$ for both). The interval did not show a significant difference between groups 2 and 3 patients $(p=0.25)$.

The most frequently observed comorbidities were hypertension $(129,26.9 \%)$, diabetes $(71,14.8 \%)$, and chronic heart diseases $(35,7.3 \%)$. The patients in group 3 were found to have significantly more $(\geq 2)$ comorbidities than other patients ( $p=0.001$ for both groups 1 and 2 ). Underlying chronic disease rates of patients in groups 1 and 2 did not differ significantly $(p=0.18)$.

Hospital stay for groups 1,2 , and 3 was $8.5 \pm 3.4,9.9 \pm 3.3$, and $12.8 \pm 5.8$ days, respectively. It was found that group 3 patients stayed for a significantly longer period in hospital than other group patients ( $p=0.001$ for both). Group 2 patients stayed for a significantly longer period of time than group 1 patients $(p=0.001)$. 
Table 1. Demographic and clinical characteristics of COVID-19 patients

\begin{tabular}{|c|c|c|c|c|}
\hline & $\begin{array}{l}\text { Group } 1 \\
(n=130) \\
\end{array}$ & $\begin{array}{l}\text { Group } 2 \\
(n=300)\end{array}$ & $\begin{array}{l}\text { Group } 3 \\
(n=49)\end{array}$ & p value* \\
\hline Age (mean \pm SD years) & $46.8 \pm 21.2$ & $49.6 \pm 17.2$ & $67.8 \pm 17.5$ & 0.001 \\
\hline Gender (male/female) & $67 / 63$ & $154 / 146$ & $20 / 29$ & 0.35 \\
\hline $\begin{array}{l}\text { Symptoms (n) (\%) } \\
\text { - Fever } \\
\text { - Fatigue } \\
\text { - Cough } \\
\text { - Nausea/vomiting } \\
\text { - Diarrhea } \\
\text { - Dyspnea } \\
\text { - Dysgeusia } \\
\text { - Anosmia }\end{array}$ & $\begin{array}{l}35(26.9 \%) \\
34(26.2 \%) \\
32(24.6 \%) \\
8(6.2 \%) \\
5(3.8 \%) \\
2(1.5 \%) \\
8(6.2 \%) \\
6(4.6 \%)\end{array}$ & \begin{tabular}{|l}
$127(42.3 \%)$ \\
$113(37.7 \%)$ \\
$156(52.0 \%)$ \\
$20(6.7 \%)$ \\
$16(5.3 \%)$ \\
$35(11.7 \%)$ \\
$21(7.0 \%)$ \\
$17(5.7 \%)$
\end{tabular} & $\begin{array}{l}25(51.0 \%) \\
29(59.2 \%) \\
31(63.3 \%) \\
5(10.2 \%) \\
6(12.2 \%) \\
26(53.1 \%) \\
2(4.1 \%) \\
1(2.0 \%)\end{array}$ & $\begin{array}{l}0.002,0.27,0.001 \\
0.02,0.007,0.001 \\
0.001,0.16,0.001 \\
1.00,0.37,0.34 \\
0.63,0.10,0.07 \\
0.001 \\
0.83,0.75,0.73 \\
0.81,0.48,0.67\end{array}$ \\
\hline $\begin{array}{l}\text { Comorbidities (n) } \\
\text { - Hypertension } \\
\text { - DM } \\
\text { - CVD } \\
\text { - COPD } \\
\text { - Cancer } \\
\text { - CKD }\end{array}$ & $\begin{array}{l}25(19.2 \%) \\
11(8.4 \%) \\
8(6.1 \%) \\
0 \\
0 \\
0\end{array}$ & \begin{tabular}{|l}
$79(26.4 \%)$ \\
$48(16.1 \%)$ \\
$21(7.0 \%)$ \\
$9(3 \%)$ \\
$3(1.0 \%)$ \\
$5(1.7 \%)$ \\
\end{tabular} & $\begin{array}{l}25(51.0 \%) \\
12(24.5 \%) \\
6(12.2 \%) \\
7(14.3 \%) \\
0 \\
0\end{array}$ & $\begin{array}{l}0.14,0.001,0.001 \\
0.046,0.15,0.01 \\
0.83,0.24,0.21 \\
0.06,0.001,0.001 \\
0.55,1.00,- \\
0.32,1.00,-\end{array}$ \\
\hline $\begin{array}{l}\text { Comorbidity number } \\
\geq 2(\%)\end{array}$ & $0 \%$ & $1.3 \%$ & $32.7 \%$ & 0.001 \\
\hline Interval (between onset of symptoms and admission, days) & $1.7 \pm 2.2$ & $4.2 \pm 3.9$ & $3.4 \pm 3.2$ & $0.001,0.18,0.002$ \\
\hline $\begin{array}{l}\text { Laboratory on admission } \\
\text { - Lymphocyte number }(/ \mu \mathrm{l}) \\
\text { - Neutrophil/lymphocyte } \\
\text { - CRP }(\mathrm{mg} / \mathrm{l}) \\
\text { - ALT (U/I) } \\
\text { - AST (U/I) } \\
\text { - D-dimer }(\mathrm{mcg} / \mathrm{l}) \\
\text { - Ferritin }(\mathrm{mcg} / \mathrm{l}) \\
\text { - Procalcitonin }(\mathrm{mcg} / \mathrm{l})\end{array}$ & $\begin{array}{l}1746.9 \pm 705.3 \\
2.6 \pm 1.8 \\
9.8 \pm 29.7 \\
19.6 \pm 18.0 \\
20.9 \pm 21.9 \\
476.7 \pm 1057.8 \\
119.6 \pm 112.7 \\
0.04 \pm 0.05 \\
\end{array}$ & $\begin{array}{l}1507.7 \pm 598.3 \\
2.8 \pm 1.7 \\
20.6 \pm 33.5 \\
27.0 \pm 23.4 \\
24.5 \pm 13.5 \\
522.0 \pm 1071.7 \\
220.4 \pm 243.0 \\
0.06 \pm 0.1 \\
\end{array}$ & $\begin{array}{l}1114.3 \pm 440.6 \\
4.4 \pm 3.0 \\
66.1 \pm 65.5 \\
28.8 \pm 24.1 \\
39.9 \pm 30.7 \\
1559.0 \pm 2093.7 \\
410.5 \pm 395.2 \\
0.3 \pm 1.0 \\
\end{array}$ & $\begin{array}{l}0.001 \\
0.35,0.001,0.001 \\
0.001 \\
0.001,0.62,0.006 \\
0.09,0.001,0.001 \\
0.73,0.001,0.008 \\
0.001,0.01,0.001 \\
0.43,0.001,0.001\end{array}$ \\
\hline $\begin{array}{l}\text { Chest CT } \\
\text { - Ground-glass appearance } \\
\text { - Infiltration } \\
\text { - Consolidation } \\
\text { - Bilateral involvement } \\
\text { - Multilobular involvement }\end{array}$ & $\begin{array}{l}0 \\
0 \\
0 \\
0 \\
0 \\
\end{array}$ & \begin{tabular}{|l|}
$282(94.0 \%)$ \\
$70(23.3 \%)$ \\
$87(29.0 \%)$ \\
$196(65.3 \%)$ \\
$155(51.7 \%)$ \\
\end{tabular} & $\begin{array}{l}41(83.7 \%) \\
16(32.7 \%) \\
24(48.9 \%) \\
37(75.5 \%) \\
38(77.6 \%) \\
\end{array}$ & $\begin{array}{l}-, 0.001,- \\
-, 0.21,- \\
-, 0.005,- \\
-, 0.16,- \\
-, 0.001,-\end{array}$ \\
\hline $\begin{array}{l}\text { Treatment } \\
\text { - Hydroxychloroquine } \\
\text { - Favipiravir } \\
\text { - Lopinavir/ritonavir } \\
\text { - Azithromycin } \\
\text { - Levofloxacin } \\
\text { - Moxifloxacin } \\
\text { - Second-/third-generation cephalosporins } \\
\text { - Oseltamivir } \\
\text { - Convalescent plasma }\end{array}$ & $\begin{array}{l}125(96.1 \%) \\
0 \\
0 \\
42 \\
24 \\
3 \\
4 \\
54 \\
0 \\
\end{array}$ & \begin{tabular}{|l}
$293(97.6 \%)$ \\
0 \\
$2(0.66 \%)$ \\
144 \\
102 \\
24 \\
22 \\
190 \\
0 \\
\end{tabular} & $\begin{array}{l}42(85.7 \%) \\
26(53 \%) \\
8(16.3 \%) \\
14 \\
22 \\
12 \\
10 \\
33 \\
3 \\
\end{array}$ & \\
\hline Hospital-stay days (mean \pm SD) & $8.2 \pm 3.4$ & $9.6 \pm 3.4$ & $13.7 \pm 5.5$ & 0.001 \\
\hline Patients in ICU (n) & 0 & 0 & 32 & \\
\hline Mortality (n) \% & 0 & $2(0.66 \%)$ & $8(16.32 \%)$ & 0.001 \\
\hline
\end{tabular}

${ }^{*} \mathrm{P}<0.05$ denotes significance. Values correspond to comparisons between groups 1 and 2, 2 and 3, 3 and 1, respectively. The single value applies to all comparisons. 


\section{Laboratory and Radiologic Findings}

It was found that 446 (93.1\%) of enrolled patients had RT-PCR positivity for SARS-CoV-2, and $33(6.9 \%)$ had rapid antibody test positivity with typical chest CT findings.

The mean lymphocyte numbers (normal range: 600-3400/ $\mu l)$ were significantly lower in patients of groups 2 and $3 \quad(1507.7 \pm 598.3 / \mu \mathrm{l}, \quad p=0.001) \quad(1114.3 \pm 440.6 / \mu \mathrm{l}, \quad p=0.001)$ than group $1(1746.9 \pm 705.3 / \mu l)$. The ratio of neutrophils to lymphocytes ( $\mathrm{N} / \mathrm{L} \%)$ was significantly higher in group 3 patients $(4.4 \pm 3)$ than groups 1 and $2(2.6 \pm 1.8$ and $2.8 \pm 1.7$, respectively, $p=0.001$ for both).

CRP levels (normal range: $0-5 \mathrm{mg} / \mathrm{l}$ ) were significantly higher in group 3 patients $(66.1 \pm 65.5 \mathrm{mg} / \mathrm{l})$ compared to that of groups 1 and $2(9.8 \pm 9.7$ and $20.6 \pm 33.5$, respectively, $p=0.001$ for both). It was also found to be significantly higher in group 2 patients than that of group $1(\mathrm{p}=0.001)$. Procalcitonin levels (normal range: $0.04-0.1 \mathrm{mcg} / \mathrm{l})$ increased significantly in group 3 compared to groups 1 and 2 patients, $p=0.03$ and 0.001 , respectively. A significant increase was found in the D-dimer levels (normal range: $0-440 \mathrm{mcg} / \mathrm{l})$ of patients in group 3 compared to that of groups 1 and 2, $p=0.008$ and $p=0.01$, respectively. Ferritin levels (normal range: $10-120 \mathrm{mcg} / \mathrm{l}$ ) increased significantly with severity of the disease ( $p=0.001$ for both groups 1 versus 2 and $3, p=0.01$ for groups 2 and 3 ).

Aspartate aminotransferase (normal range: 0-35 U/I) levels increased significantly in group 3 patients as compared to that of other groups ( $p=0.001$ for each group). Alanine aminotransferase (normal range: 0-35 $\mathrm{U} / \mathrm{l}$ ) levels were significantly higher in groups 2 and 3 patients as compared to that of group 1, $p=0.001$ and $p=0.01$, respectively.

Radiologic investigations revealed that common findings were ground-glass appearance $(323,67.4 \%)$ and consolidation (111, 23.2\%). The ground-glass appearance on chest CT was significantly more frequent in group 2 patients as compared to group $3(p=0.018)$. Consolidated areas were significantly more common in group 3 than group 2 patients $(p=0.005)$. Bilateral lung involvement was not significantly different in groups 1 and 2 and observed in 233 patients (48.6\%); however, multilobular involvement was significantly higher in group $3(p=0.001)$.

Thirty-two patients (65.3\%) in group 3 were admitted to the intensive care unit. The mortality rate was $2.1 \%$ for all groups. It was significantly higher in group 3 compared to group 2 patients $(p=0.001)$. No death was seen in group 1 .

\section{Treatment Protocol}

The treatment protocol was determined according to the updated National Ministry of Health Public Health Office COVID-19 (SARS-CoV-2 infection) guideline. The protocol included hydroxychloroquine and favipiravir, oseltamivir for possible influenza, and azithromycin or levofloxacin or moxifloxacin depending on the attending physician's choice for both synergistic action and their effects on atypical bacterial agents. Some patients received second-or third-generation cephalosporin antibiotics as per physician's recommendation. All patients were given low-molecular-weight heparin in prophylactic or therapeutic doses.

\section{Discussion}

The first COVID-19 case in Turkey was declared on March 10, 2020 by the Ministry of Health. Since March 15 COVID-19 cases were admitted to the pandemic hospital in İzmir city. Cases increased gradually from then on during the eleventh week and peaked at third and fourth weeks and tended to decrease after the sixth week (Figure 1). Similarly globally, daily case numbers peaked at the fourth and fifth weeks and tended to decrease after the sixth week (Figure 2) ${ }^{[9]}$. Tedros Ghebreyesus, M.D., the General Director of the WHO reported at the end of June that the worse did not come yet ${ }^{[10]}$.

In this study, 446 (93.1\%) out of 479 had RT-PCR positivity for SARS-CoV-2, and the remaining 33 patients $(2.4 \%)$ had rapid antibody positivity with concurrent typical radiologic findings despite RT-PCR negativity. We investigated RT-PCR from nasopharyngeal and oropharyngeal swabs two times for the presence of typical radiologic findings. Li et al. ${ }^{[11]}$ detected RT-PCR positivity in $27.5 \%$ of 384 patients with suspicious COVID-19 on first assays and 12.5\% positivity in second times.

We described the demographic and clinical features of confirmed COVID-19 patients admitted to the pandemic hospital in izmir. The mean age of patients was $50.7 \pm 19.3$ years, and 242 (50.5\%) were male. Patients were categorized into three groups based on their clinical severity and laboratory investigations. No significant difference was found in gender distribution within groups. Zhou et al. ${ }^{[12]}$ reported a similar finding: the mean age of

Daily New Cases in Turkey

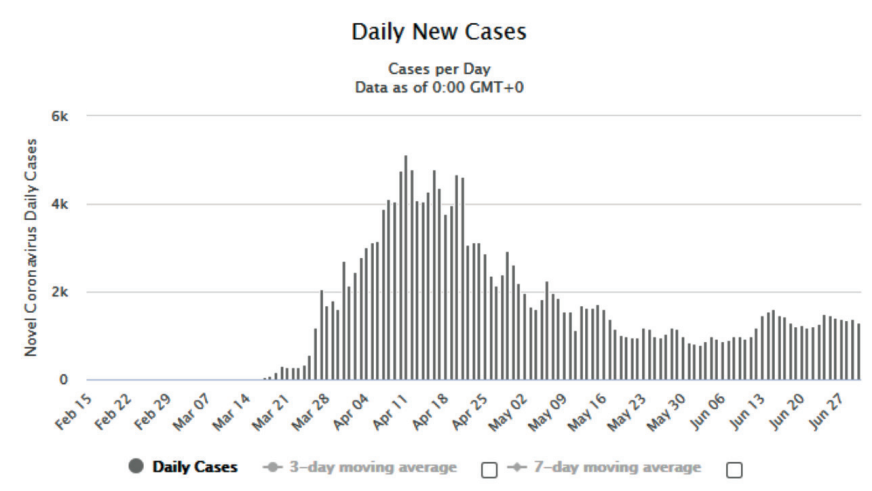

Figure 1. Daily new cases 


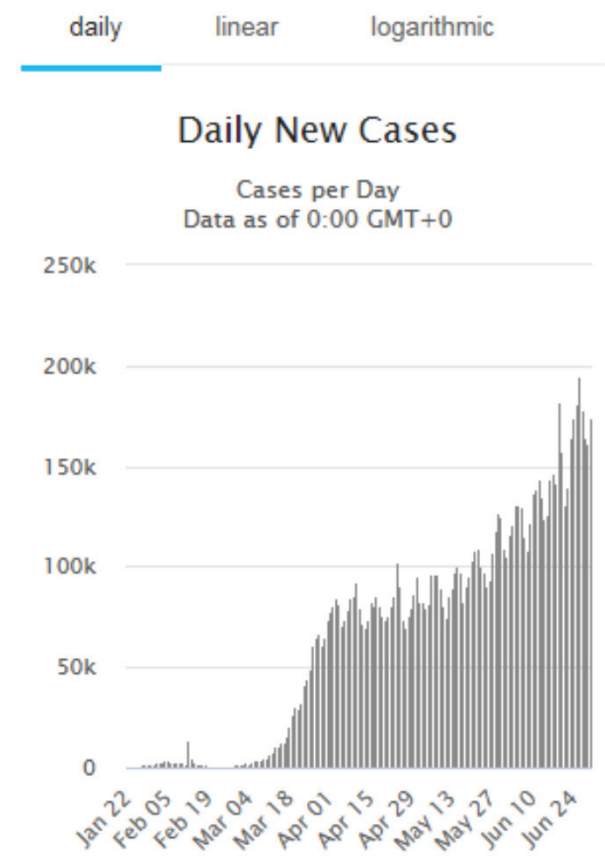

Figure 2. The global trend of cases

patients in their study was 56 years, and there was no significant difference between sex frequencies.

Fever, cough, and fatigue were observed to be the common symptoms in all groups. The ratio of cough was significantly higher in groups 2 and 3 than group 1 patients $(p=0.001$ for both). The findings in our study were compatible with the results of a meta-analysis by Li et al. ${ }^{[13]}$. They reported that fever $(88.5 \%)$, cough (68.6\%), and fatigue and myalgia (35.8\%) were prominent symptoms in 1,994 patients with a varying degree of disease severity.

In all groups, the prevalence of underlying diseases in decreasing frequency comprised hypertension (26.9\%), diabetes mellitus (14.8\%), and cardiovascular diseases (7.3\%). Guan et al. ${ }^{[14]}$ reported that hypertension (16.9\%) and diabetes mellitus (8.2\%) were the most prevalent comorbidities in COVID-19 patients. We suggested that this finding could not be attributed specifically to COVID-19 as they are the more common chronic diseases encountered in the general population. The rate of the patients with more than two comorbidities was significantly more in group 3 than groups 1 and 2 ( $p=0.001$ for both). There was no significant difference between the rates of patients with more than two comorbidities in groups 1 and 2 . As expected, the higher the number of the underlying disease, the more severe form of disease we can face up.

The laboratory investigations on admission revealed that lymphocyte numbers decreased, and N/L ratio and CRP levels increased significantly with disease progression. D-dimer, ferritin, and procalcitonin levels were found to be significantly higher in patients with severe disease compared to uncomplicated and mild/moderate disease groups. We suggested that these parameters indicated poor prognosis in COVID-19 patients with varying degrees of disease severity. The study by Chen et al. ${ }^{[15]}$ pointed out a progressive increase in these parameters with the disease progression. They showed that median lymphocyte numbers, CRP, D-dimer, ferritin, and procalcitonin levels in patients cured versus patients who died were $1.0(0.7-1.4) \times 10^{9} / 1$ versus $0.6(0.4-0.7) \times 10^{9} / \mathrm{l}, 26.2 \mathrm{mg} / \mathrm{l}$ versus $113 \mathrm{mg} / \mathrm{l}, 600 \mu \mathrm{g} / \mathrm{l}$ versus $4,600 \mu \mathrm{g} / \mathrm{l}, 481 \mu \mathrm{g} / \mathrm{l}$ versus $1,418 \mu \mathrm{g} / \mathrm{l}$, and 0.05 versus $0.33 \mathrm{ng} / \mathrm{ml}$, respectively.

The radiologically ground-glass appearance was the prominent finding in both groups 2 and 3 patients. Bilateral involvement was seen over $60 \%$ of patients in both groups and did not show a significant difference. However, multilobular involvement, consolidations, and infiltrations of lung fields were more frequent in group 3 patients. In a recent study by Xu et al. ${ }^{[16]}$, over 50\% of patients had bilateral/multifocal pulmonary involvements, and $72 \%$ of patients had a ground-glass appearance; $13 \%$ and $12 \%$ of patients with more severe disease displayed consolidation and paving-stone appearance on chest CT images, respectively.

During the study period, the guide proposed by National Scientific Working Group for COVID-19 recommended hydroxychloroquine therapy for all suspicious and confirmed patients except for pregnant patients ${ }^{[8]}$. Those patients with the corrected OT interval by Bazett formula $<480 \mathrm{~ms}$ on their electrocardiography were given hydroxychloroquine $400 \mathrm{mg}$ twice for the first day followed by $200 \mathrm{mg}$ twice daily for 4 days. Patients with severe pneumonia received either favipiravir monotherapy or with hydroxychloroquine combination. Lopinavir/ritonavir treatment was prescribed for more severe cases and pregnant patients. Ten patients among all the study patients had received lopinavir/ritonavir therapy. As per the preference of the attending physician, a respiratory quinolone or macrolide antibiotics were added to the therapy for 423 (88.3\%) patients. For seasonal influenza that could not be ruled out during the first weeks of the pandemic, we started oseltamivir to $277(57.8 \%)$ of patients who were not given favipiravir.

Only three patients got immune convalescent plasma as the study included early periods of the pandemic. Anticytokine therapy was not applied to any patient in the study groups. In a study from China, authors declared that antiviral agents such as neuraminidase inhibitors, ganciclovir, acyclovir, and ribavirin were ineffective in COVID-19 patients. They recommended the use of remdesivir or lopinavir/ritonavir with or without interferon- $\beta$, convalescent plasma, and monoclonal antibody ${ }^{[17]}$. As an expert opinion in a multicenter study from China, the use of chloroquine for patients with pneumonia was recommended in a dose of $500 \mathrm{mg}$ twice a day for 10 days ${ }^{[18]}$. 
Favipiravir (T-705; 6-fluoro-3-hydroxy-2-pyrazine carboxamide) is a potent selective antiviral agent that inhibits RNA-dependent RNA polymerase enzyme of RNA viruses. It is effective against influenza viruses including resistant strains. Favipiravir can be a promising agent for difficult-to-treat RNA viral infections ${ }^{[19]}$. We observed the efficacy of favipiravir in our study, especially in the early phase of the disease in patients with bilateral multisegmental pulmonary involvements when initiated early. Therefore, as the drug could be obtained easily during the last weeks of the study, we prefered to use it more frequently.

Remdesivir is a broad-spectrum antiviral agent primarily developed to be used in Ebola virus infections. It acts to decrease viral RNA multiplication by inhibiting RNA polymerase and exonuclease. Some in vitro studies demonstrated the efficacy of remdesivir to coronaviruses such as SARS-CoV and MERS$\mathrm{CoV}^{[20,21]}$. Remdesivir is not available in our country, therefore, it could not be used in this study.

In our study population, 32 out of 479 patients (6.7\%) were admitted to the intensive care unit, and 8 patients (25\%) died because of respiratory collapse. Among patients followed in COVID-19 positive wards $(477 ; 93.3 \%)$, two of them $(0.44 \%)$ died, and the cause of death could not be infered. The total mortality rate was 2.08\% (10 patients). A recent study reported that the disease was more severe in elderly and male patients ${ }^{[12]}$. In our study, mortality was found to be high in the elderly also but did not differ between sexes. This result could be because of the admitted patients in the first wave were from a nursing home where women predominated.

The major limitation of the study is that COVID-19 has an enormous number of clinical, pathogenic, and therapeutic unknowns. At the time of paper writing, the guidelines especially for management and therapy have been updating. Therefore new therapeutic strategies might change the management in upcoming surges.

\section{Conclusion}

Although there have been still many unknowns about COVID-19 disease pathogenesis and management from the point of scientific and public views all around the world, the first wave provided us valuable experiences about how to get organized, the importance of constructing exceptional hospitals and healthcare teams, and raising awareness about infection control measures. Conspicuously our clinical observations suggested that severe disease may develop not only in elderly but also in those $<40$ years of age, and patients without underlying diseases may suffer severe disease as well. We suggest that if we commence antiviral agents early, especially to patients with bilateral multisegmental pulmonary involvement, we can control the disease progression effectively. The primary determinant of disease severity is the interaction between host defense and virus, therefore, the extent of damage of the disease can not be predicted initially. However, the determination of some clinical findings and prognostic markers can give us clues to predict the progression of the disease. If we keep these experiences at hand and track the current guidelines timely, it will facilitate the management of COVID-19 patients in the upcoming surges. We recommend updating the therapy in the light of recent guidelines during the second wave.

\section{Ethics}

Ethics Committee Approval: The study were approved by the İzmir Tepecik Training and Research Hospital of Clinical Research Ethics Committee (protocol number: 2020/8-26, date: 08.07.2020).

Informed Consent: Consent form was filled out by all participants.

Peer-review: Externally and internally peer-reviewed.

\section{Authorship Contributions}

Surgical and Medical Practices: G.E., G.A.B., Ö.Y., F.Ş.Y., Ç.P., G.A., A.R.Ö., A.H.I., Concept: S.E., A.H.I., Design: O.A., A.H.i.., Data Collection or Processing: G.E., G.A.B., Ö.Y., F.Ş.Y., C..P., G.A., A.R.Ö., S.E., Analysis or Interpretation: G.E., G.A.B., O.A., A.H.I., Literature Search: G.E., G.A.B., Ö.Y., F.Ş.Y., Ç.P., G.A., A.R.Ö., O.A., N.Ş., Writing: O.A., A.H.I.

Conflict of Interest: No conflict of interest was declared by the authors.

Financial Disclosure: The authors declared that this study received no financial support.

\section{References}

1. Phelan AL, Katz R, Gostin LO. The novel coronavirus originating in Wuhan, China: challenges for global health governance. JAMA. 2020;323:70910.

2. Coronaviridae Study Group of the International Committee on Taxonomy of Viruses. The species severe acute respiratory syndrome-related coronavirus: classifying 2019-nCoV and naming it SARS-CoV-2. Nat Microbiol. 2020;5:536-44.

3. Guan W, Ni Z, Hu Y, Liang W, Ou C, He J, Liu L, Shan H, Lei C, Hui DSC, Du B, Li L, Zeng G, Yuen KY, Chen R, Tang C, Wang T, Chen P, Xiang J, Li S, Wang J, Liang Z, Peng Y, Wei L, Liu Y, Hu Y, Peng P, Wang J, Liu J, Chen Z, Li G, Zheng Z, Qiu S, Luo J, Ye C, Zhu S, Zhong N, for the China Medical Treatment Expert Group for Covid-19. Clinical characteristics of coronavirus disease 2019 in China. N Engl J Med. 2020;382:1708-20.

4. Chen N, Zhou M, Dong X, Qu J, Gong F, Han Y, Qiu Y, Wang J, Liu Y, Wei Y, Xia J, Yu T, Zhang $X$, Zhang L. Epidemiological and clinical characteristics of 99 cases of 2019 novel coronavirus pneumonia in Wuhan, China: a descriptive study. Lancet. 2020;395:507-13.

5. Velavan TP, Meyer CG. The COVID-19 epidemic. Trop Med Int Health. 2020;25:278-80.

6. Sethuraman N, Jeremiah SS, Ryo A. Interpreting diagnostic tests for SARSCov-2. JAMA. 2020;323:2249-51. 
7. Colson $\mathrm{P}$, Rolain JM, Lagier JC, Brouqui $\mathrm{P}$, Raoult D. Chloroquine and hydroxychloroquine as available weapons to fight COVID-19. Int J Antimicrob Agents. 2020;55:105932.

8. The Turkish Republic, The Ministry of Health Public Health Office. COVID-19 (SARS-CoV-2 Infection) guideline. Last accessed date: 2020 April 14. Available from: https://hsgm.saglik.gov.tr/depo/birimler/goc_sagligi/ covid19/rehber/COVID-19_Rehberi20200414_eng_v4_002_14.05.2020.pdf

9. Worldometers. Last accessed date: 2020 June 15. Available from: https:// www.worldometers.info/coronavirus/

10. World Health Organization warns 'the worst is yet to come' in the Covid-19 pandemic because the global crisis is 'speeding up'. Last accessed date: 2020 June 30. Available from: https://www.dailymail.co.uk/news/article-8473755

11. Li Y, Yao L, Li J, Chen L, Song Y, Cai Z, Yang C. Stability issues of RT-PCR testing of SARS-CoV-2 for hospitalized patients clinically diagnosed with COVID-19. J Med Virol. 2020;92:903-8.

12. Zhou F, Yu T, Du R, Fan G, Liu Y, Liu Z, Xiang J, Wang Y, Song B, Gu X, Guan L,

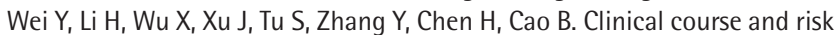
factors for mortality of adult inpatients with COVID- 19 in Wuhan, China: a retrospective cohort study. Lancet. 2020;395:1054-62.

13. Li LQ, Huang T, Wang YQ, Wang ZP, Liang Y, Huang TB, Zhang HY, Sun W, Wang Y. COVID-19 patients' clinical characteristics, discharge rate, and fatality rate of meta-analysis. J Med Virol. 2020;92:577-83.

14. Guan WJ, Liang WH, Zhao Y, Liang HR, Chen ZS, Li YM, Liu XQ, Chen RC, Tang CL, Wang T, Ou CQ, Li L, Chen PY, Sang L, Wang W, Li JF, Li CC, Ou LM, Cheng B, Xiong S, Ni ZY, Xiang J, Hu Y, Liu L, Shan H, Lei CL, Peng YX, Wei L, Liu Y, Hu YH, Peng P, Wang JM, Liu JY, Chen Z, Li G, Zheng ZJ, Qiu SQ, Luo J, Ye CJ, Zhu SY, Cheng LL, Ye F, Li SY, Zheng JP, Zhang NF, Zhong NS, He JX; China Medical Treatment Expert Group for COVID-19. Comorbidity and its impact on 1590 patients with COVID-19 in China: a nationwide analysis. Eur Respir J. 2020;55:2000547.

15. Chen $T$, Wu D, Chen $H$, Yan W, Yang D, Chen $G$, Ma K, Xu D, Yu H, Wang $H$, Wang T, Guo W, Chen J, Ding C, Zhang X, Huang J, Han M, Li S, Luo X, Zhao $J$, Ning Q. Clinical characteristics of 113 deceased patients with coronavirus disease 2019: retrospective study. BMJ. 2020;368:m1091.

16. Xu X, Yu C, Qu J, Zhang L, Jiang S, Huang D, Chen B, Zhang Z, Guan W, Ling $Z$, Jiang $R$, Hu T, Ding Y, Lin L, Gan Q, Luo L, Tang $X$, Liu J. Imaging and clinical features of patients with 2019 novel coronavirus SARS-CoV-2. Eur J Nucl Med Mol Imaging. 2020;47:1275-80.

17. Li H, Wang YM, Xu JY, Cao B. Potential antiviral therapeutics for 2019 Novel Coronavirus. Zhonghua Jie He He Hu Xi Za Zhi. 2020;43:170-2.

18. Multicenter collaboration group of Department of Science and Technology of Guangdong Province and Health Commission of Guangdong Province for chloroquine in the treatment of novel coronavirus pneumonia. [Expert consensus on chloroquine phosphate for the treatment of novel coronavirus pneumonia]. Zhonghua Jie He He Hu Xi Za Zhi. 2020;43:E019.

19. Furuta $Y$, Komeno T, Nakamura T. Favipiravir (T-705), a broad spectrum inhibitor of viral RNA polymerase. Proc Jpn Acad Ser B Phys Biol Sci. 2017;93:449-63.

20. Al-Tawfiq JA, Al-Homoud AH, Memish ZA. Remdesivir as a possible therapeutic option for the COVID-19. Travel Med Infect Dis. 2020;34:101615.

21. Singh AK, Singh A, Singh R, Misra A. Remdesivir in COVID-19: A critical review of pharmacology, pre-clinical and clinical studies. Diabetes Metab Syndr. 2020;14:641-8. 